\title{
Using genre theory for teaching writing at tertiary level: A practical example of teaching to write effective recounts
}

\author{
María Martínez-Lirola' \\ Universidad de Alicante (España) \\ Research Fellow, Department of Linguistics and Modern Languages, \\ University of South Africa (UNISA) (Sudáfrica)
}

Recibido: febrero 3 de 2015 - Revisado: febrero 16 de 2015 - Aceptado: mayo 11 de 2015

Referencia formato APA: Martínez-Lirola, M. (2015). Using genre theory for teaching writing at tertiary level: A practical example of teaching to write effective recounts. Revista Cientifica Guillermo de Ockham, 13(1), 59-66.

\begin{abstract}
The study reported in this paper focuses on the use of Genre Theory as an appropriate framework for English L2 writing in the subject English Language III of the degree course in English Studies. We analysed 115 recounts written by students on this course at the University of Alicante (Spain) after they had studied different text types following Genre Theory. This Theory was applied in order to increase students' literacy skills through the study of text types and specific grammatical characteristics that appear in these texts. This study will show that using the Theory of Genre as a framework to teach academic writing helped students to improve their writing skills. The results of the texts analysed suggest that exposing students to good models of different text types, paying special attention to recounts, and asking them to write texts based on these models, improves students' texts from the grammatical and the textual point of view.
\end{abstract}

Keywords: Genre theory, text types, academic writing, teaching-learning process, errors, recount

\section{Uso de la Teoría del Género para enseñar escritura en la Universidad: Un ejemplo práctico de enseñar a escribir recounts efectivos}

\section{Resumen}

El estudio que se analiza en este artículo se centra en el uso de la teoría del género como un marco adecuado para la enseńanza de la escritura en inglés como segunda lengua en la asignatura Lengua Inglesa III, del grado en Estudios Ingleses. Se analizaron 115 recounts escritos por estudiantes de dicha asignatura en la Universidad de Alicante (España) una vez que habían estudiado los distintos tipos de textos de acuerdo con la teoría del género. Esta teoría se aplicó con

\footnotetext{
* Este artículo se deriva del proyecto de investigación Redes de Investigación en Docencia Universitaria, titulado Reflexión sobre una experiencia de aprendizaje colaborativo en filología inglesa. Dicho proyecto de investigación se llevó a cabo desde noviembre de 2013 hasta noviembre de 2014.

1. Doctora en Filología Inglesa y profesora titular de la Universidad de Alicante. Directora del grupo de investigación Análisis Crítico del Discurso Multimodal. Dirección postal: Universidad de Alicante, Departamento de Filología Inglesa, Ap. 99 E-03080 Alicante (Espańa). E-mail: Maria.lirola@ ua.es
} 
el fin de que el alumnado mejorara su capacidad de escribir a través del estudio de textos y las características específicas gramaticales que aparecen en ellos. Este estudio mostrará que usar la teoría del género como marco para enseñar escritura académica, ayudó al alumnado a mejorar sus destrezas escritas. Los resultados de los textos analizados sugieren que exponer al alumnado a distintos modelos de tipos de textos, con especial importancia a los recount y pedirles que escriban textos basados en estos modelos, mejora los textos del alumnado desde el punto de vista gramatical y textual.

Palabras clave: Teoría del género, tipos de textos, escritura académica, proceso de enseñanza-aprendizaje, errores, recount

\section{Usando a teoria de gênero para ensinar a escrever na Universidade: um exemplo prático de escrever recounts eficazes}

\section{Resumo}

O estudo discutido neste artigo enfoca o uso da teoria de gênero como um quadro de ensino de escrita em Inglês como segunda língua grau de Inglês III em Estudos Ingleses do curso. 115 recontagens escritas foram analisadas por estudantes de este assunto na Universidade de Alicante (Espanha), uma vez que tinha estudado os vários tipos de textos seguintes teoria de gênero. Esta teoria foi aplicada aos alunos melhorar a sua capacidade de escrita através do estudo de textos e características gramaticais específicas que aparecem nelas. Este estudo mostra que o uso da teoria de gênero como um quadro para ensinar escrita acadêmica alunos ajudou a melhorar suas habilidades de escrita. Os resultados dos textos analisados sugerem que expor os alunos a diferentes tipos de modelos de texto, com especial atenção para a recontagem, e pedir-lhes para escrever textos com base nesses modelos, melhora textos dos alunos a partir do ponto de vista gramatical e textual.

Palavras Chave: Teoria de gênero, tipos de textos, escrita acadêmica, processo ensino-aprendizagem, erros, recount

\section{Introduction}

Academic writing is one of the skills students have more difficulties with due to the fact that it is difficult to combine the appropriate vocabulary, grammar and syntax in order to create coherent and cohesive texts that are suitable in a particular context. In this sense, it is important that students are aware that they can do things with the texts they write: they can complain, give information, persuade, etc. Writing for real life involves that students are aware of the potential of language and that they choose language depending on the function of the text they are asked to write. This implies being aware of the power of language to do things in the texts, in Halliday's words (1978, p. 27): "Language, [...] is a potential: it is what the speaker can do".

The following table, adapted from de Sylva Joyce and Burns, (1999, p. 42), highlight some principles that we consider essential in our teaching practice. As we can see, one of the main ideas is the fact that language and society are related and that it is the context that determines the language that should be used according to the purpose of the communicative situation:

Table 1

Teaching principles in our teaching practice

\begin{tabular}{|c|c|}
\hline $\begin{array}{l}\text { Teaching } \\
\text { principles }\end{array}$ & Teaching practice \\
\hline $\begin{array}{l}\text { View of } \\
\text { language }\end{array}$ & $\begin{array}{l}\text { Grammatical choices depend on how language is } \\
\text { used to make meaning in context. }\end{array}$ \\
\hline $\begin{array}{l}\text { View of } \\
\text { language } \\
\text { learning }\end{array}$ & $\begin{array}{l}\text { Learning is organic and developmental. Learners } \\
\text { form hypothesis about grammatical systems } \\
\text { through language use in social contexts. }\end{array}$ \\
\hline $\begin{array}{l}\text { Learning } \\
\text { objectives }\end{array}$ & $\begin{array}{l}\text { To develop competent, appropriate and indepen- } \\
\text { dent use of language for communicative purposes. }\end{array}$ \\
\hline Role of teacher & $\begin{array}{l}\text { Classrooms are learner-centred. Teachers conduct } \\
\text { needs analysis, provide relevant activities, promote } \\
\text { language use for communicative purposes, monitor } \\
\text { learner progress and encourage learner autonomy. }\end{array}$ \\
\hline Role of learner & $\begin{array}{l}\text { Learners are active processors of content. They } \\
\text { make hypothesis about language use and gram- } \\
\text { matical structure. }\end{array}$ \\
\hline $\begin{array}{l}\text { Classroom } \\
\text { activities }\end{array}$ & $\begin{array}{l}\text { Text-based tasks related to specific contexts and } \\
\text { integrated to meet spoken and written language } \\
\text { needs. }\end{array}$ \\
\hline $\begin{array}{l}\text { Materials and } \\
\text { resources }\end{array}$ & $\begin{array}{l}\text { Materials selected to relate to learner needs, inclu- } \\
\text { ding authentic spoken and written texts, videos, } \\
\text { audio recordings and teacher-made materials. }\end{array}$ \\
\hline
\end{tabular}

Fuente: Adaptado de Joyce \& Burns (1999, p. 42). 
The approach to academic writing based on Genre Theory requests the use of authentic texts as models of texts that are successful to accomplish communicative ends in a determined context. The Genre Theory uses authentic texts to introduce students to the main text types, to their functions and to their textual and grammatical characteristics; this approach shows that language is a resource to express meanings and to accomplish communicative ends in context, following Wennerstrom (2003, p. 34): "In a genre approach, the social and historical contexts of writing are given a higher priority: it is acknowledged that the conventions of written genres have a social history, having been developed in the context of a culture with communication needs and goals."

The Genre Theory is the approach chosen in this article due to its suitability to interpret language and context and for its practical application to the analysis of authentic texts that can help students to write good texts by observing models of authentic pieces of writing. Thus, in this paper we intend to show that Genre Theory is a very suitable approach for the interpretation of 'text and context' and 'language learning and development'. The application of Genre Theory to the analysis of texts is essential in order to help students to write better or more easily, which is crucial in social interaction (Hua, Seedhouse, Li \& Cook, 2007, p. 1).

Having the Genre Theory as a framework our intention is to pay attention to the importance of the organization of information at text level, and to see the text as a social product reflecting the social context in which it is written since there is a connection between form and meaning. Using authentic texts in the teaching-learning process implies that students are able to observe the potential of the texts as carriers of social meaning and how the texts selected are essential to reflect social situations (MartínezLirola, 2013).

\section{Approaching Genre Theory}

As already mentioned in the previous section, following Halliday (1978), we understand language in general and writing in particular as 'meaning potential' (what can be said), i.e. what the speaker can do or mean, which implies that out of the different choices that are possible in language, the speaker selects the most appropriate ones according to the communicative situation or the functions that language has in context, rather than a set of rules ('what must be said'). In this way we are interested in a systemic functional approach to language because of the interrelationship between language, text and the contexts in which those texts occur (Martínez-Lirola, 2005, p. 76).

There are some recent studies that pay attention to academic writing as an important skill that students need to develop in order to know the conventions of different text types that they might need in life. Some of these studies reinforce the importance of academic literacies (Coffin \& Donohue, 2012; Gardner, 2012; Klein \& Unsworth, 2014). Other studies concentrate on the importance of literacy and on the different approaches to writing (Fang \& Schleppegrell, 2010; Klein \& Yu, 2013; Schleppegrell, 2011; Wingate, 2012). In addition, there are other studies that join genre theory with the use of computer assisted language learning (CALL) (Hsien-Chin, 2000, MartínezLirola \& Tabuenca-Cuevas, 2008-2010; Pérez-Gutiérrez $\&$ Pérez-Torres, 2005).

Texts that share the same purpose in the culture and have many of the same obligatory and optional features are called genres or text types. Genre and Genre Theories are concerned with the relationship between the structure and shape of texts in order to be effective in a particular context and to achieve the goals of a particular culture. The genre approach highlights that language is used in different ways depending on the different contexts in which it is used and on the things that want to be accomplished in a particular culture (Biber, 2006; Kress, 2003; Parodi, 2010; Wennerstrom, 2003).

Since the Genre Theory concentrates on the analysis of written and spoken discourse and our corpus of study consists of written texts (see section 3), it is essential that students know different tools to analyse written texts and are aware of the different genres or text types. In this way, the Genre approach has a crucial role in literacy since it concentrates on both the production and analysis of texts in a given language (Martin \& Rose, 2012; Moyano, 2013; Swales, 2002; Wennerstrom, 2003). It offers the tools for the analysis of grammatical features in written texts, such as: the different stages of texts, theme and rheme position, lexical choices (e.g., technical vocabulary, descriptive vocabulary, vocabulary of judgement or attitude), types of verbs, noun groups (including nominalization, extended noun groups), cohesion (types of conjunctions, types of reference, substitution, ellipsis, lexical cohesion). Consequently, the text has a central category in literacy, following Fairclough's words (2003, p. 65), "[...] genres are the specifically discoursal aspect of ways of acting and interacting in the course of social events [...]". 
The role of the teacher in the development of students' writing is crucial because she/he needs to make students feel confident during the writing process so that students are successful in the process of developing their literacy (Carrasquillo \& Rodríguez, 2008; Coffin, 2001; Edelsky, 2006; Fenstermacher \& Soltis, 2009; Hasan, 1989). Teachers can accept many roles during the teaching-learning process. The main one is that of facilitator, although she/ he can have other roles such as guidance or tutor, among others (Martínez-Lirola, 2007).

\section{Methodology and main steps in our research}

\section{Objectives, participants and context}

The main objective of the research presented in this paper is to develop a "genre-based pedagogy" in a University language classroom classrooms so that students are able to see a connection between writing and social life (De Silva \& Feez, 2012; Fecho, 2011; Herrington, Hodgson \& Moran, 2009; Hubbard \& Levy, 2006; Martínez-Lirola, 2006; Trofimovich \& McDonough, 2011), in Drury's words (2004, p. 233): "This pedagogy engages students in an interactive teaching/learning cycle where they acquire knowledge, understanding, practice in and feedback on the target genres and apply this in producing their own texts for particular purposes".

The subject English Language III is a core subject in the degree in English Studies (Grado en Estudios Ingleses). Its main purpose is that students develop the five skills in English (listening, speaking, reading, writing and interaction). The subject was taught during four hours a week that were divided in the following sections: one hour for oral presentations and interaction, another hour for grammar and vocabulary, one hour for reading comprehension and finally, the last hour was devoted to writing. Consequently, English Language III deals with academic writing for upper intermediate students in English.

During the academic year 2013-2014 there were 123 students registered in the subject. There were 105 women and 18 men. Most of them were Spanish but there was also a small number of Erasmus students from France, Germany and Poland (7 women). There were so many students registered in this subject because apart from being a core subject in English Studies, the subject is offered as an optional course for students in the degrees French Studies, Spanish Studies and Arabic Studies, which implies that there are different levels of English in the classroom.
All the students have studied English in primary and secondary education and during the first year of the degree in the core subjects English Language I and II. Most of the students wanted to be English teachers at the high school. There were also students who wanted to work as translators or interpreters.

\section{Procedure}

\section{Research design and research questions.}

At the beginning of the semester students worked at sentence and paragraph level in the writing activities. Then, in the second half of the semester students were introduced to the main text types following Butt, Fahey, Spinks and Yallop, (2000) and Droga and Humphrey (2003), whose approach is framed by the model of Genre Theory proposed by the Sydney School. Consequently, the main text types that these authors propose are the following: recount, narrative, procedure, information report, explanation, exposition and discussion. Good models of the previous text types were used in the classroom so that students could observe the different stages in every text type and their main grammatical characteristics. Moreover, it was emphasized the social purpose of the different texts.

After having introduced the main characteristics of the different text types and having analysed some good models such in detail, the concept of Generic Structure Potential (hereafter GSP) was introduced to refer to the range of textual structures available within a genre, in Hasan's words (1984, p. 79), the GSP is "descriptive of the total range of textual structures available within a genre $G^{\prime}$; it includes those elements that are obligatory, all elements of structure that are optional, and the order in which obligatory and optional elements should appear.

Once students had been introduced to the main text types in English and had been introduced to the GSP of the said texts, they were asked to describe the generic text structure of some examples of recount so that they could observe the different stages in the construction of the text. Students were also asked to observe the main grammatical and structural features in sample texts. Next, students were assigned writing tasks in which they had to write two paragraphs that were going to be part of a recount. These paragraphs were corrected and commented on by the teacher with each student in an individualised tutorial before the students moved on to a larger writing assignment which implied writing a full recount. 
Then, at the end of the semester of the academic year 2013-2014 students registered in the subject English Language III of the degree in English Studies were asked to write a complete recount following the models introduced in the practical sections devoted to academic writing. The total amount of texts analysed were 115 , i.e., there were 8 students who did not hand in the text and therefore they had to do it the day of final exam at the end of the semester.

The teacher marked the recounts paying attention to the main grammatical features (see section 4 where the results and the specific characteristics of recounts are presented) and also to the textual characteristics of this text type, i.e., observing if students have followed the structure of the text, which is clearly connected with its communicative end.

With the analysis we intended to answer the following research questions: what are the main difficulties students have to write recounts? and to what extent does the use of the Genre Theory helps students to improve their writing from the textual and the grammatical point of view?.

\section{Results and discussion}

The "recount" is a form of writing that tells what happened, documents a sequence of events and evaluates their significance in some way (Butt. et al., 2000, p. 217; Droga \& Humphrey, 2003, p. 141). The basic structure of this text consists on an orientation, a record of events and a reorientation and a coda (these last two are optional). Moreover, the main grammatical features of it are the following (Butt. et al., 2000, p. 218-223; Droga \& Humphrey, 2003, p. 141): use of particular and general nouns, use of action verbs, use of conjunctions and adverbials to refer to time, lexical cohesion by collocations, repetitions and synonyms and evaluative language.

Due to the limitations of this paper, we are just going to offer one example of a recount written by an English Language III student. This example is representative of the main structural and grammatical characteristics found in the recounts under analysis. As we can see, this student has followed the structural aspects of a recount because we observe a clear orientation followed by the records of events and finally, the text ends with a coda. However, although there are some grammatical characteristics of recounts, the student has some difficulties with the grammar elements appropriate to this text type (see example below).

\section{Example of a recount written by a University student}

\section{Orientation}

When I finished university lessons, I decided to spend my summer by Preposition doing something else that went VForm to the beach. In summer, I always move in Preposition Torrevieja. In that city, there are summerjobs for students a lot WOrder. I applied for several jobs and I was succeeded VForm WChoice in a great number of them. However, job hunting was not as grateful??? it seems to be.

\section{Record of Events}

In my first interview, I knew that I must not have gotten the job before finishing it. It was due to the fact that I was not experience ${ }^{V T e n s e}$ at all in this field. $\underline{\mathrm{In}}^{\text {Preposition }}$ the third??? interview I realized that the bar was a night - club , thus I went quickly home WOrder! In the second and fourth ones, I was able of obtaining VForm the job. $\underline{\mathrm{In}}$ Preposition these occasions, I felt confident of myself.

The second interview was completely different from the former. The recruiter was told that I was experienced in check - out. Thus, the head of personal called me for an interview. When I arrived at the supermarket, a girl took my résumé and carried the to head personal it WOrder. In five minutes I was led to ${ }^{M i s s i n g} W_{\text {interviewer's office. }}$ There, I was asked about my previous experience too. Then, I was sat VForm for a personality and content test. I had the most terrible time! I had been prepared VTense before-hand what I was going to say and I ha done a monkey's work ??? I thought that job interviews were ${ }_{\mathrm{a}}{ }^{A r t}$ face-to-face interaction in order to get as much information as possible. However, by that time I must have proved valuable.???

\section{Coda}

It is supposed that job interviews are simple $A w k w a r d$ phrasing, quickly WForm and effective WForm when applicants are called for an interview. Both applicant and employer might treat each other as equals. In that sense, $A r t$ interview is seen as an exchange of information. However, it is not always the case. When applying for an interview, it is sometimes a long effort - $A r t_{\text {consuming process and }}$ in most of the cases a frustrating one.

As we can observe in the corrections made by the teacher that are clearly indicated in red and blue in the text above, the student had great difficulty in maintaining 
correct word order which impeded the correct use of linking words and structures. The multiple errors with prepositions made meaning at times indecipherable and the use of reference linking and conjunctions were at a minimum if they existed at all. In regards to grammar, the student was not able to adequately use the past tenses in order to create a coherent sequence of events. This also impeded the effectiveness of the dependent clauses, which many times had no relevance to the main sentence.

However, this text has several characteristics of recounts such as the use of particular and general nouns (summer, interview job, etc.), use of action verbs (apply, arrive, recruit, etc.), use of conjunctions and adverbials to refer to time (after that, then), in Torrevieja, etc.), lexical cohesion by collocations (summer-beach; job hunting-recruitment, etc.), repetitions (interviews, job, experience, etc.) and synonyms (enquire, ask, etc.) and evaluative language (lonely, shock, etc.). In addition, most students (86 out of the 115 who wrote a recount) structured their texts in a coherent and cohesive way whereas the others had written texts with a very poor structure. It was observed that 31 students had problems with the use of transitions. This goes together with the fact that they had the tendency to cluster ideas in one sentence. In essence, we observe that the following the Genre approach helps students establish a relationship between grammar and textuality in order to improve their writing skills.

As proponents of the genre approach we argue that making the genres explicit and showing how to write them will help students to be aware of how knowledge is structured in different disciplines. It will also allow them to deal with the various written genres used in their context of culture and to see language as a dynamic and social phenomenon, which helps to understand the social context of a text.

Adopting Genre Theory as a theoretical framework make students aware of the relationship between the structure and shape of texts in order to be effective in their context, and to achieve the goals of their culture. Making genres explicit and showing how to write them help students to be aware of how knowledge is structured in different written genres depending on the text type, as we can observe in the example of a recount already analysed.

\section{Conclusions}

Using the Genre Theory as a framework for teaching academic writing and for the analysis of our corpus enabled greatly enhanced insights into the text. It offers instruments to analyse aspects related to form (i.e. paragraph division) and content in any text, and it concentrates on the function or purpose of the text. In this way, the text is understood as a social product.

This approach helps students observe that they can understand a culture by paying attention to all texts that are produced in that culture. Genre Theory helps students to learn that texts cannot be considered autonomously because they always go together with historical, social, economic, among others factors.

This study has shown that the Genre Theory gives students the opportunity of studying the purposes of different genres and how genres use different language and structures to accomplish their purposes. By doing so, students become aware of the impact of language choices in the way the text is received by the audience.

In addition, this approach to learning academic writing has been suitable so that students become aware of the relationship between knowledge of different genres and the potential of those languages to do things in society. In this sense, they need to explore how this knowledge is unequally distributed in society and the consequences of that distribution.

\section{References}

Biber, D. (2006). University Language. A corpus-based study of spoken and written registers. Amsterdam -Philadelphia: John Benjamins.

Butt, D., Fahey, R., Spinks, S. , \& Yallop, C. (2000). Using Functional Grammar. An Explorer's Guide. Second edition. Sydney: NCELTR.

Carrasquillo, A. L., \& Rodríguez, V. (2008). Language Minority Students in the Mainstream Classroom. Bristol: Multilingual Matters.

Coffin, C. (2001). Theoretical approaches to Written Language: A TESOL Perspective. In A. Burns \& C. Coffin (Eds.), Analysing English in a Global Context. A Reader (pp. 93-122). London: Routledge.

Coffin, C., \& Donohue, J. P. (2012). Academic Literacies and systemic functional linguistics: How do they relate? Journal of English for Academic Purposes, 11, 64-75.

De Sylva Joyce, H., \& Burns, A. (1999). Focus on Grammar. Sydney: NCELTR.

Droga, L., \& Humphrey, S. (2003). Grammar and Meaning. An Introduction for Primary Teachers. Berry NSW: Target Texts. 
Drury, H. (2004). Teaching academic writing on screen: a search for best practice. In R. Ellis \& J.L. Ravelli (Eds.), Analysing Academic Writing. Contextualised Frameworks (pp. 233-253). London: Continuum.

Edelsky, C. (2006). Literacy and Justice for All: Rethinking the Social in Language and Education (Language, Culture, and Teaching). NY: Lawrence Erlbaum Associates.

Fairclough, N. (2003). Analysing Discourse. Textual Analysis for Social Research. London: Routledge.

Fang, Z., \& Schleppegrell, M. J. (2010). Disciplinary literacies across content areas: Supporting secondary reading through functional language analysis. Journal of Adolescent \& Adult Literacy, 53, 587-597.

Fecho, B. (2011). Teaching for the Students. Habits of Heart, Mind, and Practice in the Engaged Classroom. N Y: Teachers College Press.

Fenstermacher, G. D., \& Soltis, J. F. (2009). Approaches to Teaching. NY: Teachers College Press.

Gardner, S. (2012). Genres and registers of student report writing: An SFL perspective on texts and practices. Journal of English for Academic Purposes, 11, 52-63.

Halliday, M. A. K (1978). Language as Social Semiotic: The Social Interpretation of Language and Meaning. London: Edward Arnold.

Hasan, R. (1984). The Nursery Tale as a Genre. Nottingham Linguistic Circular, 12, 71-102.

Hasan, R. (1989). The structure of the text. In M. A. K. Halliday \& R. Hasan Language, Context, and Text: Aspects of Language in a Social-Semiotic Perspective (pp. 52-69). Oxford: Oxfords University Press.

Herrington, A., Hodgson, K., \& Moran, C. (Eds.) (2009). Teaching the New Writing. Technology, Change and Assessment in the $21^{\text {st }}$ Century Classroom. NY: Teachers College Press.

Hsien-Chin, L. (2000). Assessing Learner Strategies Using Computers: New Insights and Limitations. CALL, 13(1), 65-78.

Hua, Z., Seedhouse, P, Li, W., \& Cook, V. (2007). An Introduction. In Z. Hua, P. Seedhouse, W. Li \& V. Cook (Eds.), Language Learning and Teaching as Social Inter-action (pp. 1-5). London: Palgrave Macmillan.

Hubbard, P., \& Levy, M. (2006). The scope of CALL education. In P. Hubbard \& M. Levy (Eds.), Teacher Education in CALL (pp. 3-20). Amsterdam/Philadelphia: John Benjamins.

Klein, P., \& Unsworth, L. (2014). The logogenesis of writing to learn: A systemic functional perspective. Linguistics and Education, 26, 1-17.

Klein, P. D., \& Yu, A. M. (2013). Best practices in writing to learn. In S. Graham, C. A. MacArthur, \& J. Fitzgerald
(Eds.), Best practices in writing to learn. Second edition. (pp. 166-189). NY: The Guilford Press.

Kress, G. (2003). Literacy in the New Media Age. London: Routledge.

Martin, J. R., \& Rose, D. (2012). Learning to Write/Learning to Learn: Genre, Knowledge and Pedagogy in the Sydney School. London: Equinox.

Martínez-Lirola, M. (Abril, 2005). How to highlight context in academic writing from a SFL perspective. Trabajo presentado en la I Conferencia Regional Latinoamericana de Lingüistica Sistémica Funcional. Mendoza, Universidad Nacional de Cuyo-Argentina.

Martínez-Lirola, M. (2006). The importance of teaching Systemic Functional Linguistics and Text Linguistics to improve writing in Bilingual Education Programs in the USA. Porta Linguarum. Revista Internacional de Didáctica de las Lenguas Extranjeras, 5, 139-150.

Martínez-Lirola, M. (2007). El nuevo papel del profesor universitario en el proceso de convergencia europeo y su relación con la interacción, la tutoría y el aprendizaje autónomo. Porta Linguarum. Revista Internacional de Didáctica de las Lenguas Extranjeras, 7, 31-43.

Martínez-Lirola, M. (2013). Teaching visual grammar and social issues in an English language course: an example using multimodal texts on immigrant minors from a Spanish newspaper. In F.J. Díaz- Pérez, M.B. Díez-Bedmar, P. García-Ramírez \& D. Rascón-Moreno (Eds.) Global Issues and the Teaching of Language, Literature and Linguistics (pp. 195-215). Viena: Peter Lang.

Martínez-Lirola, M., \& Tabuenca Cuevas, M. (2008). Integrating CALL and Genre Theory: a Proposal to Increase Students' Literacy. RECALL, 20(1), 67-81.

Martínez-Lirola, M., \& Tabuenca-Cuevas, M. (2010). Applying Genre Theory to improve exposition-type essay writing. Revista Internacional de Didáctica de las Lenguas Extranjeras, $13,29-42$.

Moyano, E. I. (2013). (coord) Aprender Ciencias y Humanidades: una cuestión de lectura y escritura. Aprotes para la construcción de un programa de inclusión social a través de la educación lingüistica. Buenos Aires: Universidad Nacional de General Sarmiento.

Parodi, G. (2010). Written discourse genres. Towards an integral conception from a sociocognitive perspective. In G. Parodi (Ed.), Academic and Professional Discourse Genre in Spanish (pp. 17-35). Amsterdam-Philadelphia: John Benjamins.

Pérez-Gutiérrez, M., \& Pérez- Torres, I. (2005). Audio-visual resources and new technologies in ELT. In D. Madrid, N. Mclaren \& A. Bueno (Eds.), TEFL in Secondary Education (pp. 545-578). Granada: Universidad de Granada. 
Trofimovich, P., \& McDonough, K. (Eds.) (2011). Applying Priming Methods to L2 Learning, Teaching and Research. Insights from Psycholinguistics. Amsterdam-Philadelphia: John Benjamins.

Schleppegrell, M. J. (2011). Supporting disciplinary learning through language analysis: Developing historical literacy. In F. Christie, \& K. Maton (Eds.), Disciplinarity: Functional linguistic and sociological perspectives (pp. 197-216). London: Continuum International Publishing Group.

Swales, J. M. (2002). On models of applied discourse analysis. In C.N. Candlin (Ed.), Research and Practice in Professional
Discourse (pp. 61-77). Hong Kong: City University of Hong Kong Press.

Wennerstrom, A. (2003). Discourse Analysis in the Language Classroom. Volume 2. Genres of Writing. Michigan: The University of Michigan Press.

Wingate, U. (2012). Using Academic Literacies and genre-based models for academic writing instruction: A 'literacy' journey. Journal of English for Academic Purposes, 11, 26-37. 